\title{
Hydrolysis of Palatinose (Isomaltulose) by Pig Intestinal Glycosidases
}

\author{
ARNE DAHLQVIST \\ Department of Physiological Chemistry, University of Lund, Lund, Sweden

\begin{abstract}
Homogenates of intestinal mucosa from adult pigs hydrolyze palatinose (6-( $a$-D-glucopyranosyl)-D-fructose).

The palatinase activity is caused by a mixture of three separate enzymes, namely specific isomaltase, maltase II and maltase III.

These three enzymes also hydrolyze isomaltose, but the relative rates of hydrolysis of isomaltose and palatinose during the conditions used for glycosidase activity determination are different for the three enzymes.

Maltase III alone exerts about $50 \%$ of the total palatinase activity of crude homogenates of pig intestinal mucosa.
\end{abstract}

$\mathrm{T}^{\mathrm{s}}$ he isolation of a new disaccharide, palatinose (isomaltulose, (6-( $a$-D-glucopyranosyl)-D-fructose), formed by a bacterium isolated from sugar beets, was recently described by Weidenhagen and Loren $\mathrm{z}^{1-3}$. This disaccharide is hydrolysed by some species of yeast. The hydrolysis seems not, however, to be caused by maltase ( $a$-glucosidase), as might have been expected, but by a specific palatinase ${ }^{4}$.

It is not known whether the glycosidases of the intestinal mucosa are able to hydrolyze palatinose or not. This question is of interest as the effect of orally administered palatinose on intestinal flora is currently under study ${ }^{5}$. It is also important for the further characterization of the specificity of the different pig intestinal $a$-glucosidases recently separated ${ }^{6}$. Professor Weidenhagen kindly supplied the author with a sample of palatinose for the study of the action of pig intestinal glycosidases on this sugar.

\section{MATERIALS AND METHODS}

\section{Intestinal glycosidase preparations}

The mucosa and the contents of the small intestine of adult pigs were obtained by pressing the intestine between two rollers immediately after the slaughter. The whole length of the small intestine was used. In the first experiments the preparation obtained was homogenized in an Ultra-Turrax homogenizer for $2 \mathrm{~min}{ }^{7}$, and after centrifugation 
in an ordinary laboratory centrifuge for $5 \mathrm{~min}$ the opalescent supernatant was analyzed immediately. Later preparations were used which had been solubilized and thereafter purified by ethanol precipitation as described earlier ${ }^{6}$.

\section{Substrates}

Sucrose (2-( $a$-D-glucopyranosyl)- $\beta$-D-fructofuranoside) (cryst.) was obtained from Baker Co. (U.S.A.) and maltose (4-(a-D-glucopyranosyl)-D-glucose) (cryst., monohydrate) from Merck A.G. (Germany). Isomaltose (6-(a-D-glucopyranosyl)-D-glucose) and phenyl-a-Dglucopyranoside were prepared by the methods described earlier ${ }^{8,9}$. Palatinose (isomaltulose, 6-(a-D-glucopyranosyl)-D-fructose) (cryst., monohydrate) was kindly supplied by Professor R. Weidenhagen (Neuoffstein, Germany).

\section{Glycosidase activity determinations}

Methods for the determination of invertase, maltase, isomaltase and phenyl-a-D-glucopyranosidase activities have been described in a previous paper ${ }^{10}$.

Palatinase activity was determined by the use of glucose oxidase in the same way as has been described earlier for turanase and lactase activity determinations ${ }^{10}$. The substrate solution was prepared by dissolving $1.90 \mathrm{~g}$ of palatinose in $0.10 \mathrm{M}$ maleate buffer pH 6.5 to a final volume of $100 \mathrm{ml}^{*}$ (cf. Table 5 in Ref. ${ }^{10}$ ). In accordance with the other glycosidase activities one unit of palatinase activity is defined as the activity causing $5 \%$ of hydrolysis in $2.0 \mathrm{ml}$ of reaction mixture in 60 min at $37^{\circ} \mathrm{C}$.

\section{Protein determinations}

The determination of protein was performed with the method of Lowry et al.11 using the modified reagent $B$ introduced by Eggstein and Kreutz ${ }^{12}$. A standard curve was prepared with human serum albumin, kindly supplied by A. B. Kabi.

\section{Mutual displacement chromatography}

The mutual displacement technique as applied to the chromatography of glycosidases upon TEAE-cellulose columns has been described in a previous paper ${ }^{13}$. The TEAE. cellulose was prepared in the laboratory from Solkafloc cellulose powder SW $40 \mathrm{~A}^{13}$. The ion exchanger was stored and used in its bromide form. Commercial TEAE-cellulose (from Serva Entwicklungslabor, Germany) was found unsuitable for columns of the dimensions used $(1 \times 100 \mathrm{~cm})$ since the flow rate became too low.

\section{RESULTS AND DISCUSSION}

Palatinaseactivity of crudeintestinal preparations

Fresh intestinal mucosa homogenates from adult pigs hydrolyzed palatinose with a rate that was $0.3-0.5$ times the rate for the hydrolysis of isomaltose; $0.1-0.2$ times that for sucrose; and $0.02-0.05$ times that for maltose during the conditions used for glycosidase activity determination.

* Since palatinose did not decrease in weight on storage in vacuo over $\mathrm{P}_{2} \mathrm{O}_{5}$ at $50^{\circ} \mathrm{C}$ it was believed to be anhydrous. The sugar contains, however, one mole of crystal water which is difficultly removed ${ }^{5}$. The substrate solution therefore should contain $2.0 \mathrm{~g}$ of palatinose per $100 \mathrm{ml}^{10}$. The activity measured at the somewhat lower substrate concentration used here is, however, only about $2 \%$ too low.

Acta Chem. Scand. 15 (1961) No. 4 


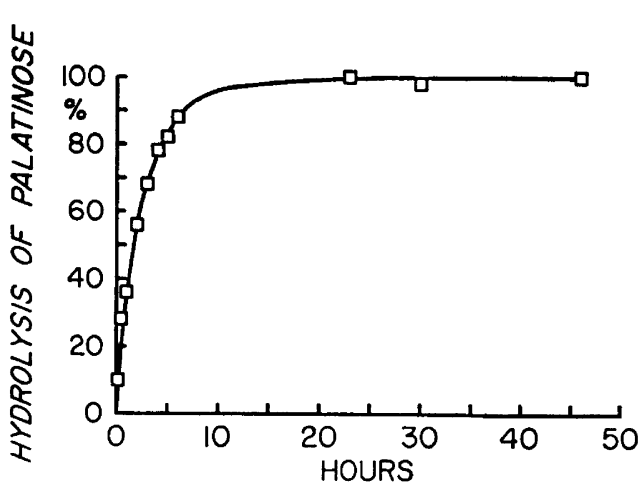

Fig. 1. Hydrolysis of palatinose by a"crude extract of pig intestinal mucosa at $0.027 \mathrm{M}$ substrate concentration in $0.05 \mathrm{M}$ maleate buffer $\mathrm{pH} 6.5$ at $37^{\circ} \mathrm{C}$. Toluene was used as a preservative. The hydrolysis proceeded to completion.

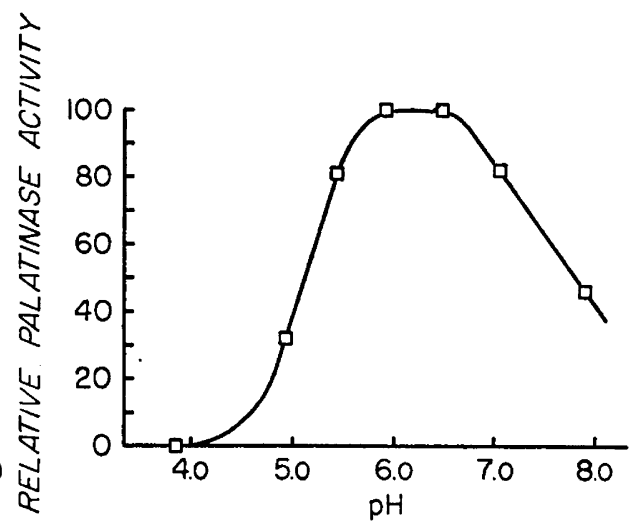

Fig. 2. Influence of $\mathrm{pH}$ on the palatinase activity of a crude extracts of pig intestinal mucosa. Substrate concentration $0.027 \mathrm{M}$ Temperature $37^{\circ} \mathrm{C}$. Buffers: $0.05 \mathrm{M}$ acetate buffer $\mathrm{pH} 4-5,0.05 \mathrm{M}$ maleate buffer $\mathrm{pH}$ $5.5-6.5$, and $0.025 \mathrm{M}$ veronal buffer $\mathrm{pH}$ $7-8$.

Solubilization of the preparation by the method described earlier ${ }^{6}$, and precipitation of the solubilized preparation with ethanol ${ }^{6,7}$, did not alter the ratio of palatinase activity to the isomaltase, invertase or maltase activity. Like these activities, therefore, the palatinase activity is undamaged by solubilization and ethanol precipitation, and for the experiments described below preparations treated in this way were used.

The hydrolysis of palatinose by crude intestinal glycosidase preparations proceeded to completion (Fig. 1). The palatinase activity had its optimum pH at $6.0-6.5$ (Fig. 2).

Experiments were then performed to determine whether the intestinal palatinase activity was exerted by a specific palatinase, as in yeast ${ }^{4}$, or by one or several of the intestinal $a$-glucosidases previously separated ${ }^{6}$.

\section{Separation of palatinase from trehalase}

The fact that the palatinase activity was undamaged by ethanol precipitation seemed to indicate that intestinal trehalase was without palatinase activity, since this enzyme is inactivated by ethanol ${ }^{\text {? }}$. This also became evident from the analysis of a purified intestinal trehalase preparation, obtained as described elsewhere ${ }^{14}$. Intestinal trehalase had no detectable palatinase activity under conditions such that hydrolysis of palatinose with a rate only $1 / 250$ of that of trehalose would have been detected.

The remaining intestinal $a$-glucosidases to be considered were: invertase (=maltase I), maltase II, maltase III, specific isomaltase and specific phenyl-aD-glucopyranosidase ${ }^{6,9}$. 


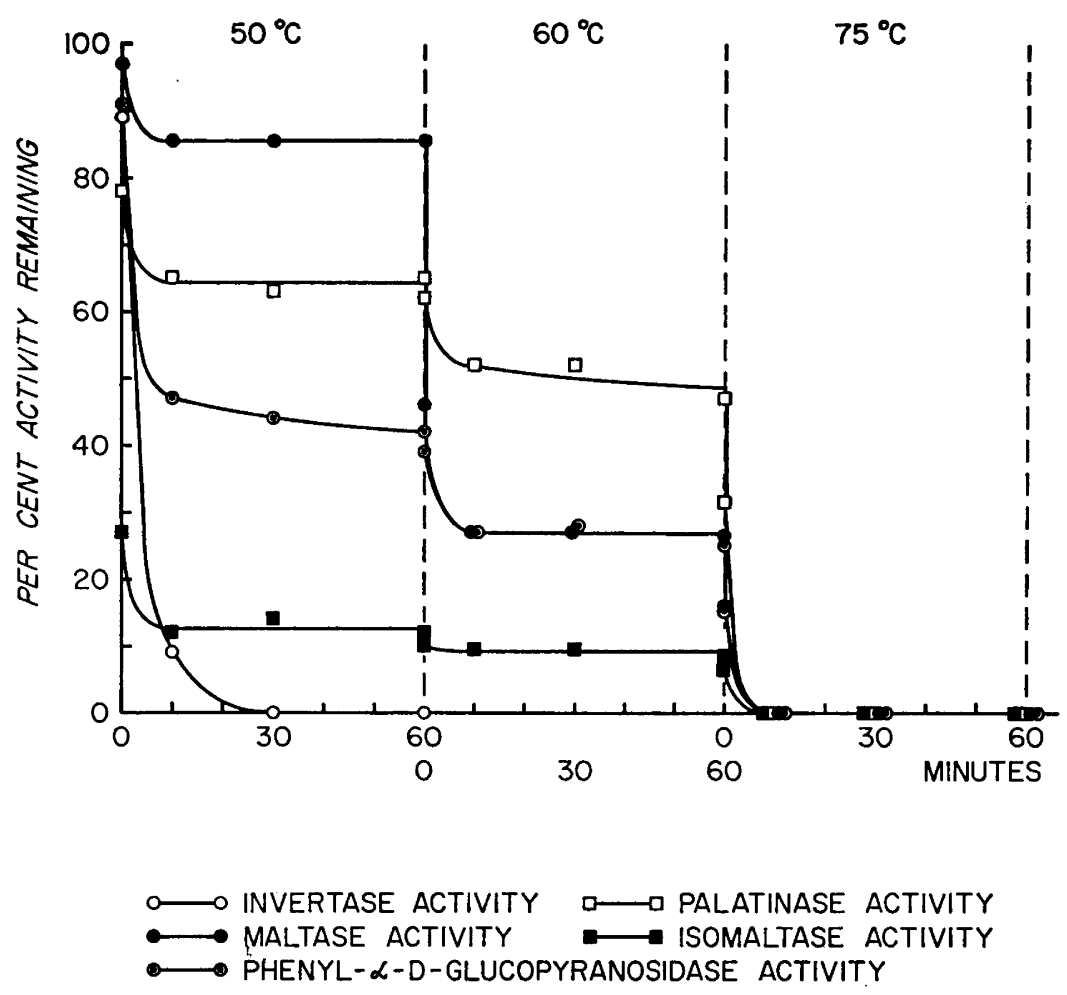

Fig. 3. Heat inactivation of intestinal $a$-glucosidases in three separate steps. The enzyme preparation contained $2.0 \mathrm{mg} / \mathrm{ml}$ of protein in $0.01 \mathrm{M}$ phosphate buffer $\mathrm{pH} 7.0$.

Step-wise heat inactivation of a

crude intestinal glycosidase preparation

It has been demonstrated earlier that the differences between pig intestinal invertase (= maltase I), maltase II and maltase III, with regard to their sensitivity to heat, is so great that these enzymes may be heat-inactivated in three separated steps under appropriate conditions ${ }^{13}$. The results of such an experiment, in which also the palatinase, isomaltase, and phenyl- $a$-D-glucopyranosidase activities were followed are seen in Fig. 3.

The solubilized crude intestinal glycosidase preparation used for this experiment contained $2.0 \mathrm{mg}$ of protein per $\mathrm{ml}$ in $0.01 \mathrm{M}$ phosphate buffer $\mathrm{pH}$ 7.0. The $a$-glucosidase activities of the preparation were as follows; invertase 93 units $/ \mathrm{ml}$, maltase (total) $350 \mathrm{units} / \mathrm{ml}$, palatinase $10.8 \mathrm{units} / \mathrm{ml}$, isomaltase (total) 30 units $/ \mathrm{ml}$ and phenyl- $a$-D-glucopyranosidase (total) 13.5 units $/ \mathrm{ml}$. The technique used for heat inactivation has been described earlier ${ }^{13}, 15$.

The heat inactivation experiment illustrated in Fig. 3 was performed at pH 7.0 at all temperatures. In the experiments previously reported, the $\mathrm{pH}$ Acta Chem. Scand. 15 (1961) No. 4 
was lowered to 6.0 before heating at $60^{\circ} \mathrm{C}^{13}$. Later this precaution was found to be unnecessary.

A. Inactivation at $50^{\circ} \mathrm{C}$. During heating at $50^{\circ} \mathrm{C}$ the invertase activity (93 units $/ \mathrm{ml}$ ) was completely abolished, together with 60 units $/ \mathrm{ml}$ of maltase activity (this fraction amounting to $17 \%$ of the total maltase activity of the preparation), (Fig. 3). This fraction of the maltase activity is known to be exerted by the invertase (=maltase I) ${ }^{16}$. The maltase/invertase activity quotient for this enzyme as calculated from the present experiment is 0.65 , which agrees well with the figure reported earlier ${ }^{10}$.

At this temperature $26 \mathrm{units} / \mathrm{ml}$ ( $87 \%$ of the total) of the isomaltase activity and $7.5 \mathrm{units} / \mathrm{ml}(56 \%)$ of the phenyl- $a-\mathrm{D}$ - glucopyranosidase activity were inactivated (Fig. 3). Since purified intestinal invertase (= maltase I) previously has been obtained which exerted neither isomaltase nor phenyl- $a$-Dglucopyranosidase activity ${ }^{8}$, these activities are caused by one or two other enzymes (specific isomaltase and specific phenyl- $\boldsymbol{a}$-D-glucopyranosidase ${ }^{6},{ }^{\mathbf{9}}$ ).

Of the palatinase activity $3.8 \mathrm{units} / \mathrm{ml}(35 \%)$ was inactivated at $50^{\circ} \mathrm{C}$ (Fig. 3). This fraction of the palatinase activity may be caused by any of the different enzymes inactivated at this temperature.

$B$. Inactivation at $60^{\circ} \mathrm{C}$. During heating at $60^{\circ} \mathrm{C}$ the maltase activity decreased by further 198 units $/ \mathrm{ml}$ ( $57 \%$ of the original maltase activity of the preparation), this fraction corresponding to the maltase II present in the preparation ${ }^{6,8,13}$. In the same time the isomaltase activity decreased by 1.5 units $/ \mathrm{ml}$ (5\% of the original value) and the phenyl- $a$-D-glucopyranosidase by 2.5 units/ml $(19 \%)$. These activities are known to be exterted by the maltase II per $s e^{8}$. The isomaltase/maltase and phenyl-a-D-glucopyranosidase/maltase activity quotients for this enzyme were both calculated to be about 0.01 . As was to be expected ${ }^{10}$ these quotients are somewhat lower than those earlier obtained with the use of more concentrated substrate ${ }^{8}$.

The palatinase activity decreased by $2.0 \mathrm{units} / \mathrm{ml}(19 \%$ of the original value) during heating at $60^{\circ} \mathrm{C}$. There seems to be reason to suppose that this part of the palatinase activity is caused by the maltase II per se. Under this assumption the palatinase/maltase activity quotient for maltase II may be calculated to be 0.01 , i.e. palatinose and isomaltose, which are structurally very similar to each other, are hydrolyzed at about the same rate by this enzyme during the conditions used for glycosidase activity determination.

C. Inactivation at $75^{\circ} \mathrm{C}$. All the glycosidase activities hitherto remaining were completely abolished during heating at $75^{\circ} \mathrm{C}$. The fraction of the maltase activity which was inactivated in this step amounted to 92 units $/ \mathrm{ml}(26 \%$ of the original activity); isomaltase, $2.5 \mathrm{units} / \mathrm{ml}(8 \%)$; phenyl- $a$-D-glucopyranosidase, 3.5 units $/ \mathrm{ml}(26 \%)$, and palatinase $5.0 \mathrm{units} / \mathrm{ml}(46 \%)$.

The fractions of the maltase, isomaltase and phenyl- $a$-D-glucopyranosidase activities inactivated in this step are known to be exerted by one single enzyme, maltase III ${ }^{8,17}$. The isomaltase/maltase activity quotient $(0.03)$ and the phenyl- $a$-D-glucopyranosidase/maltase activity quotient (0.04) calculated from the present experiment are comparable with the figures earlier obtained ${ }^{10}$. 
Using the assumption that the fraction of the palatinase activity inactivated in this step is that caused by maltase III per se, (for further evidence. for this assumption, see below), the palatinase/maltase activity quotient for this enzyme may be calculated to be 0.05 .

\author{
Palatinase activity of purified \\ invertase and maltase III preparations
}

Purified invertase (= maltase I) and maltase III were obtained by mutual displacement chromatography on TEAE-cellulose columns of a solubilized intestinal glycosidase preparation as described in a previous paper ${ }^{13}$. The concentrated phosphate buffer present in the fractions obtained was removed by dialysis, before heat inactivation experiments were performed.

A. Purified invertase (= maltase $I$ ). The invertase preparation obtained by mutual displacement chromatography contained $930 \mathrm{units} / \mathrm{ml}$ of invertase and $6.1 \mathrm{mg} / \mathrm{ml}$ of protein. It had maltase/invertase activity quotient 0.7 , and thus contained no maltase II or maltase III. The preparation had palatinase activity, 72 units $/ \mathrm{ml}$. It had, however, also isomaltase activity, 352 units $/ \mathrm{ml}$, and phenyl- $a$-D-glucopyranosidase activity, 124 units $/ \mathrm{ml}$, i.e. the preparation contained, in addition to invertase, specific isomaltase and specific phenyl-aD-glucopyranosidase.

On earlier occasions invertase preparations have been obtained by this method which had neither isomaltase nor phenyl- $a$-D-glucopyranosidase activities ${ }^{8}$. It has also been observed that the specific isomaltase is rapidly inactivated during adsorption to anion exchange cellulose ${ }^{2}$. In the present experiment it was therefore somewhat astonishing to find that the specific isomaltase activity had survived the mutual displacement chromatography which involved adsorption of the enzymes to TEAE-cellulose at room temperature $\left(20^{\circ} \mathrm{C}\right)$ for about $24 \mathrm{~h}$. As far as the author is aware the only difference between this experiment and that described earlier is that in the present case a solubilized intestinal glycosidase preparation was used, which had been stored in the frozen state $\left(-16^{\circ} \mathrm{C}\right)$ for several months, while in the eaerlier case a fresh preparation was used. Storage in the frozen state is known to affect the specific isomaltase in a complicated way, causing an initial decrease, followed by a slower increase of the activity of this enzyme ${ }^{\circ}$, and may also alter the stability of the enzyme during adsorption to TEAE-cellulose.

To reveal which enzyme in the preparation was responsible for the palatinase activity, attempts were made to separate the activities by heat inactivation. At $\mathrm{pH} 7.0$ (in $0.01 \mathrm{M}$ phosphate buffer) the palatinase and isomaltase activities were found to be more sensitive to heat than the invertase and phenyl- $a-D$ glucopyranosidase activities. The course of the inactivation at $32^{\circ} \mathrm{C}$ is seen in Fig. 4. At this temperature the palatinase and isomaltase activities were slowly inactivated, and the inactivation of these activities ran parallel, while the invertase and phenyl-a-D-glucopyranosidase activities were only very slightly affected. It seems justifiable, therefore, to suppose that the most heat-labile fraction of the palatinase activity (i.e. the fraction inactivated at $50^{\circ} \mathrm{C}$ in the experiment with the crude preparation described above) is exerted by the specific isomaltase. The palatinase/isomaltase activity quotient for this enzyme may be calculated to be 0.2 . The experiment also shows that specific isomaltase and specific phenyl- $a$-D-glucopyranosidase are two separate enzymes.

Acta Chem. Scand. 15 (1961) No. 4 

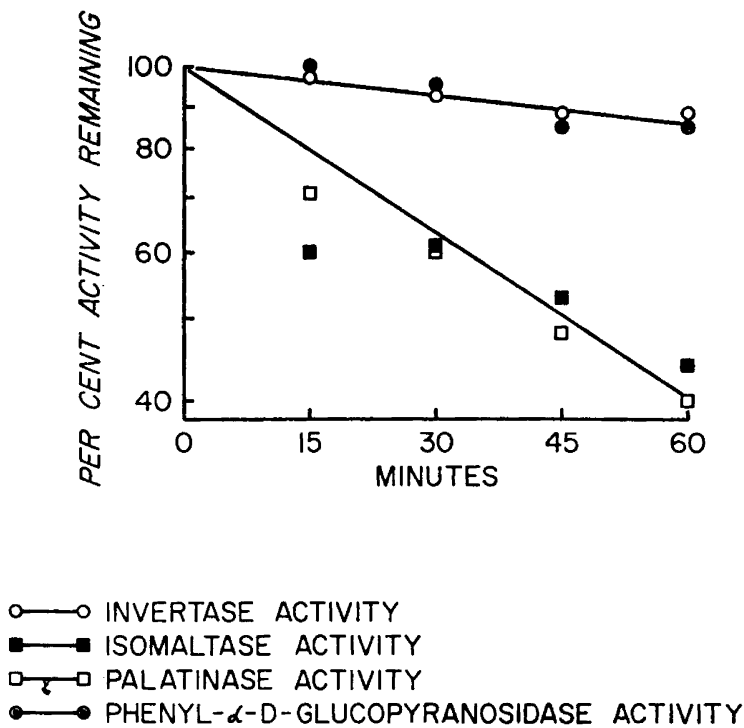

Fig. 4. Heat inactivation of a purified invertase preparation (obtained by mutual displacement chromatography) at $32^{\circ} \mathrm{C}$ in $0.01 \mathrm{M}$ phosphate buffer $\mathrm{pH} 7.0$. The preparation contained specific isomaltase and specific phenyl-a-D-glycopyranosidase as contaminants (see text). The enzyme solution used for heat inactivation contained $0.2 \mathrm{mg} / \mathrm{ml}$ of protein, $37 \mathrm{units} / \mathrm{ml}$ of invertase, $12.4 \mathrm{units} / \mathrm{ml}$ of isomaltase, $4.0 \mathrm{units} / \mathrm{ml}$ of phenyl-a-D-glucopyranosidase and $\mathbf{2 . 5}$ units $/ \mathrm{ml}$ of palatinase.

Inactivation at so low temperature as $32^{\circ} \mathrm{C}$ occurs only with purified preparations at low salt concentration. When a homogenate of intestinal mucosa was heated at $37^{\circ} \mathrm{C}$ for $2 \mathrm{~h}$, no inactivation of the glycosidase activities investigated was observed. There is therefore no reason to suppose any heat inactivation of intestinal glycosidases to occur in vivo at body temperature. Nor does inactivation occur during the conditions for glycosidase activity determinations (at $37^{\circ} \mathrm{C}$ ) even with purified preparations. Experiments with varying incubation time showed the amount of monohexoses formed during the last half hour of the incubation to be the same as the amount formed during the first half hour.

B. Purified maltase III. The purified maltase III preparation obtained by mutual displacement chromatography contained 304 units $/ \mathrm{ml}$ of maltase and $0.8 \mathrm{mg} / \mathrm{ml}$ of protein. It had no invertase activity. The preparation contained 13 units $/ \mathrm{ml}$ of isomaltase, $15 \mathrm{units} / \mathrm{ml}$ of phenyl-a-D-glucopyranosidase and 22 units $/ \mathrm{ml}$ of palatinase. The isomaltase and phenyl- $a$-D-glucopyranosidase activities of the preparation are known to be caused by the maltase III per $s e^{8,10,17}$.

During heating of the preparation at $71^{\circ} \mathrm{C}$ (in $0.01 \mathrm{M}$ phosphate buffer $\mathrm{pH}$ 6.0) the maltase and palatinase activities of this preparation were inactivated in a parallel manner, indicating the palatinase activity of this preparation to be also caused by the maltase III per se (Fig. 5). The palatinase/maltase activity quotient for this enzyme was calculated to be 0.06 .

Acta Chem. Scand. 15 (1961) No. 4 

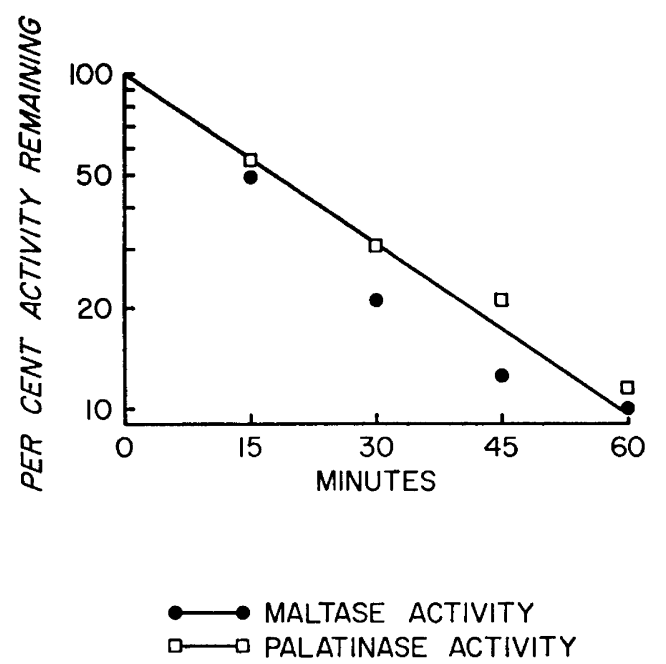

Fig. 5. Heat inactivation of a purified maltase III preparation at $71^{\circ} \mathrm{C}$ in $0.01 \mathrm{M}$ phosphate buffer $\mathrm{pH}$ 6.0. The enzyme solution used for heat inactivation contained $0.15 \mathrm{mg} / \mathrm{ml}$ of protein, 55 units $/ \mathrm{ml}$ of maltase and $2.6 \mathrm{units} / \mathrm{ml}$ of palatinase.

\section{Relations between palatinase and is o maltase activity}

From the experiments described above, it appears that palatinose is hydrolyzed by the same intestinal glycosidases as hydrolyze isomaltose, i.e. specific isomaltase, maltase $I I$ and maltase $I I I$. This is in harmony with the structural similarity between the two substrates. It is apparent that none of the enzymes is absolutely specific for the structure around the lst and 2 nd carbon atom of the aglycon of the substrate.

Nevertheless the structural difference between isomaltose and palatinose causes marked differences in the relative rates of hydrolysis of the two substrates by the different en zymes. During the conditions used for glycosidase activity determinations specific isomaltase hydrolyzes palatinose with a rate that is only one fifth of the rate for hydrolysis of isomaltose by the same enzyme. Maltase $I I$ hydrolyzes the two substrates at approximately the same rate, and maltase III hydrolyzes palatinose nearly twice as fast as isomaltose.

These differences make maltase III the most important enzyme for the hydrolysis of palatinose by crude extracts of intestinal mucosa, for this enzyme causes about $50 \%$ of the total palatinase activity of such preparations, although it causes only about $10 \%$ of the total isomaltase activity.

Acknowledgement. This investigation has been supported by grants from the Swedish Medical Research Council. Mrs. K. Hagebris and Miss A. Hansson are acknowledged for skillful technical assistance.

Acta Chem. Scand. 15 (1961) No. 4 


\section{REFERENCES}

1. Weidenhagen, R. and Lorenz, S. Z. Zuckerind. 7 (1957) 533.

2. Weidenhagen, R. and Lorenz, S. Angew. Chem. 69 (1957) 641.

3. Lorenz, S. Z. Zuckerind. 8 (1958) 535.

4. Emeis, C. C. and Windisch, S. Z. Zuckerind. 10 (1960) 248.

5. Weidenhagen, R. Personal communication.

6. Dahlqvist, A. Hog Intestinal a-Glucosidases. Diss. Lund 1960.

7. Borgström, B. and Dahlqvist, A. Acta Chem. Scand. 12 (1958) 1997.

8. Dahlqvist, A. Acta Chem. Scand. 14 (1960) 1.

9. Dahlqvist, A. Acta Chem. Scand. 14 (1960) 72.

10. Dahlqvist, A. Acta Chem. Scand. 14 (1960) 1797.

11. Lowry, O. H., Rosebrough, N. J., Farr, A. L. and Randall, R. J. J. Biol. Chem. 193 (1951) 265 .

12. Eggstein, M. and Kreutz, F. H. Klin. Wochschr. 33 (1955) 879.

13. Dahlqvist, A. Acta Chem. Scand. 13 (1959) 1817.

14. Dahlqvist, A. Acta Chem. Scand. 14 (1960) 9.

15. Dahlqvist, A. Acta Chem. S'cand. 13 (1959) 945.

16. Dahlqvist, A. Acta Chem. Scand. $14(1960) 63$.

17. Dahlqvist, A. Acta Chem. Scand. 13 (1959) 2156.

Received December 8, 1960. 